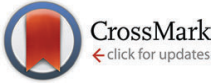

Cite this: New J. Chem., 2015, 39, 4471

Received (in Montpellier, France) 12th January 2015 Accepted 24th March 2015

DOI: $10.1039 / c 5 n j 00085 h$

www.rsc.org/njc

\title{
2D assemblies of ionic liquid crystals based on imidazolium moieties: formation of ion-conductive layers $\uparrow$
}

\author{
Junji Sakuda, ${ }^{a}$ Masafumi Yoshio, ${ }^{a}$ Takahiro Ichikawa, ${ }^{\mathrm{b}}$ Hiroyuki Ohno ${ }^{\mathrm{b}}$ and \\ Takashi Kato*ac
}

Ionic liquid-based 2D ion-conductive liquid crystals were obtained by the co-assembly of imidazolium salts and cationic calamitic liquid crystals with an imidazolium moiety at the end of the molecule through a flexible spacer. They exhibit smectic A phases. The two components are compatible over a wide range of compositions for ionic liquids with various anions. This organization of ionic liquids enhances the ionic conductivities of calamitic ionic liquid crystals. These liquid-crystalline mixtures dissolve lithium salts. The 2D ion-conductive pathways formed by the ionic liquid crystals and ionic liquids act as ion-conductive media for lithium ions

\section{Introduction}

Nanostructured liquid crystals ${ }^{1}$ are emerging as new functional materials for various applications such as ion ${ }^{2}$ and charge ${ }^{3}$ transport, separation membranes, ${ }^{4}$ and catalysis. ${ }^{5}$ Nanosegregation ${ }^{1,6,7}$ is one approach to control the structures of self-assembled liquid-crystalline (LC) molecules. The incompatible parts segregate at the molecular scale, leading to the formation of various complex nanostructures. The organization of functional molecules into LC nanostructures through this approach is a promising strategy for the development of next-generation functional materials.

Ionic liquids ${ }^{8}$ are organic salts and they melt below room temperature. They have received a lot of attention as electrolyte materials because of their negligible vapor pressure, ${ }^{9}$ flame retardancy,$^{10}$ and high ionic conductivity. ${ }^{11}$

The development of ionic-liquid-based liquid crystals through nanosegregation enables the formation of ion-conductive pathways, through which ions are efficiently transported in the desired directions. ${ }^{1,2,12-17}$ These nanostructured ion-conductive liquid crystals have potential as new functional electrolytes for electrochemical devices; ${ }^{2 j, 18}$ for example, smectic liquid crystals containing ionic liquids have been recently found to efficiently transport $\mathrm{I}^{-} / \mathrm{I}_{3}{ }^{-}$redox couples and have also been used in

\footnotetext{
${ }^{a}$ Department of Chemistry and Biotechnology, School of Engineering,

The University of Tokyo, Hongo, Bunkyo-ku, Tokyo 113-8656, Japan. E-mail: kato@chiral.t.u-tokyo.ac.jp

${ }^{b}$ Department of Biotechnology, Tokyo University of Agriculture and Technology, Nakacho, Koganei, Tokyo 184-8588, Japan

${ }^{c}$ CREST, JST, 4-1-8 Honcho, Kawaguchi, Saitama 332-0012, Japan

$\dagger$ Electronic supplementary information (ESI) available. See DOI: 10.1039/c5nj00085h
}

dye-sensitized solar cells. ${ }^{18}$ High-temperature stable operation of the cells was achieved using ionic-liquid-based liquid crystals.

The aim of the present study is to construct highly mobile ion-conductive pathways using the self-assembly of ionic liquid crystals and ionic liquids. Ionic liquids are organized to form ion-conductive pathways through nanosegregation and interactions with ionic LC molecules. The free migration of ions is expected to provide high ionic conductivity. Diol-based LC molecules have been developed as another approach to the organization of ionic liquids. ${ }^{15-17}$ In these diol systems, the interactions between the hydroxyl groups and ionic liquids are well-designed for the co-assembly of the two components. There is a restriction on the chemical structures of the ionic liquids that can be incorporated into LC nanostructures; for example, a columnar assembly of LC structures ${ }^{15}$ comprising a diol-based fan-shaped molecule and an ionic liquid was achieved only for ionic liquids with $\mathrm{Br}^{-}$anions. The use of ionic liquid crystals as LC molecules is an approach that is applicable to a wide variety of ionic liquids and gives more stable LC structures. In the present design, the segregation of the ionic and non-ionic moieties of ionic liquid crystals and ionic liquids leads to the facile formation of LC nanostructures. There have not been many reports on the ion-conductive LC assemblies obtained using this approach of mixing ionic liquid crystals and ionic liquids. ${ }^{13 b}$ More extensive studies of the LC and ion-conductive properties of the mixtures of ionic liquid crystals and ionic liquids for future applications are needed. ${ }^{2 j, 18}$

Herein, we report 2D ion-conductive LC mixtures consisting of calamitic ionic liquid crystals containing imidazolium cations and imidazolium ionic liquids. Ionic liquids with various anions have been used to induce efficient $2 \mathrm{D}$ ion-conductive pathways 
in the ionic liquid crystals. Recently, we reported, for the first time, that lithium-ion batteries can be operated using 2D ionconductive liquid crystals. ${ }^{2 j}$ It is therefore important to examine 2D LC ion-conductive materials for the further development of electrochemical devices.

\section{Results and discussion}

\section{Molecular design}

Calamitic ionic liquid crystals $\mathbf{1}(\mathbf{X})$ ( $\mathbf{X}$ is an anion) with an imidazolium moiety at the end of the molecule were designed and synthesized for the formation of LC layered structures (Fig. 1). The cyclohexylphenyl mesogen is covalently attached through an alkyl spacer to the imidazolium cation. $\mathrm{BF}_{4}{ }^{-}, \mathrm{CF}_{3} \mathrm{SO}_{3}{ }^{-}$, and $\left(\mathrm{CF}_{3} \mathrm{SO}_{2}\right)_{2} \mathrm{~N}^{-}$were chosen as the counter anions. For the ionic liquids, 1-ethyl-3-methylimidazolium ionic liquids 2(X) with various anions $\left[\mathrm{BF}_{4}{ }^{-}, \mathrm{CF}_{3} \mathrm{SO}_{3}{ }^{-}\right.$, and $\left.\left(\mathrm{CF}_{3} \mathrm{SO}_{2}\right)_{2} \mathrm{~N}^{-}\right]$were used because of their high ionic conductivities. ${ }^{11,19}$ Compounds $2(\mathrm{X})$ are expected to be organized into layered nanostructures by mixing with $\mathbf{1}(\mathbf{X})$ through nanosegregation, leading to the formation of highly mobile pathways.

\section{Liquid-crystalline properties of the ionic liquid crystals}

The phase transition behavior of $\mathbf{1}(\mathbf{X})$ is summarized in Table 1. Compounds $\mathbf{1}(\mathrm{X})$ exhibit smectic A phases; this indicates the formation of $2 \mathrm{D}$ ion-conductive pathways (ESI, $\dagger$ Fig. S1-S6). The order of isotropization temperature is $\mathbf{1}\left(\mathbf{B F}_{4}\right)>\mathbf{1}\left(\mathbf{C F}_{3} \mathbf{S O}_{3}\right)>$ $\mathbf{1}\left(\left(\mathbf{C F}_{3} \mathbf{S O}_{2}\right)_{2} \mathbf{N}\right)$. This temperature order is inversely related to the order of the radii of the counter anions. ${ }^{20}$ These results suggest

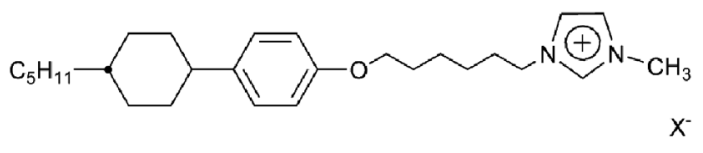

1(X): $\mathrm{X}=\mathrm{BF}_{4}, \mathrm{CF}_{3} \mathrm{SO}_{3},\left(\mathrm{CF}_{3} \mathrm{SO}_{2}\right)_{2} \mathrm{~N}$

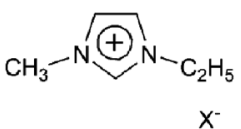

$2(\mathrm{X}): \mathrm{X}=\mathrm{BF}_{4}, \mathrm{CF}_{3} \mathrm{SO}_{3},\left(\mathrm{CF}_{3} \mathrm{SO}_{2}\right)_{2} \mathrm{~N}$

Fig. 1 Molecular structures of the ionic liquid crystals $\mathbf{1}(\mathrm{X})$ and ionic liquids $2(\mathrm{X})$

Table 1 Thermal properties of compounds $1(X)$

\begin{tabular}{lllllll}
\hline $\mathrm{X}$ & \multicolumn{2}{l}{ Radius of $\mathrm{X}^{-a}(\mathrm{\AA})$} & \multicolumn{4}{c}{ Phase transition behavior ${ }^{b, c}$} \\
\hline $\mathrm{BF}_{4}$ & 2.29 & & $250^{d}$ & $\mathrm{SmA}$ & $35^{e}(10)$ & $\mathrm{Cr}$ \\
$\mathrm{CF}_{3} \mathrm{SO}_{3}$ & 2.70 & Iso & $148(1.1)$ & $\mathrm{SmA}$ & $35(22)$ & $\mathrm{Cr}$ \\
$\left(\mathrm{CF}_{3} \mathrm{SO}_{2}\right)_{2} \mathrm{~N}$ & 3.24 & Iso & $64(1.6)$ & $\mathrm{SmA}$ & &
\end{tabular}

${ }^{a}$ Ref. 20. ${ }^{b}$ Transition temperatures $\left({ }^{\circ} \mathrm{C}\right)$ and transition enthalpies $\left(\mathrm{kJ} \mathrm{mol}^{-1}\right.$, in parentheses) are determined by differential scanning calorimetry (DSC) on the first cooling at a scan rate of $10 \mathrm{~K} \mathrm{~min}^{-1}$. ${ }^{c}$ Iso: isotropic; SmA: smectic A; Cr: crystalline. ${ }^{d}$ Thermal degradation occurs around $250{ }^{\circ} \mathrm{C}$ before the isotropization was observed.

${ }^{e}$ Observed on the 1 st cooling from $100{ }^{\circ} \mathrm{C}$.

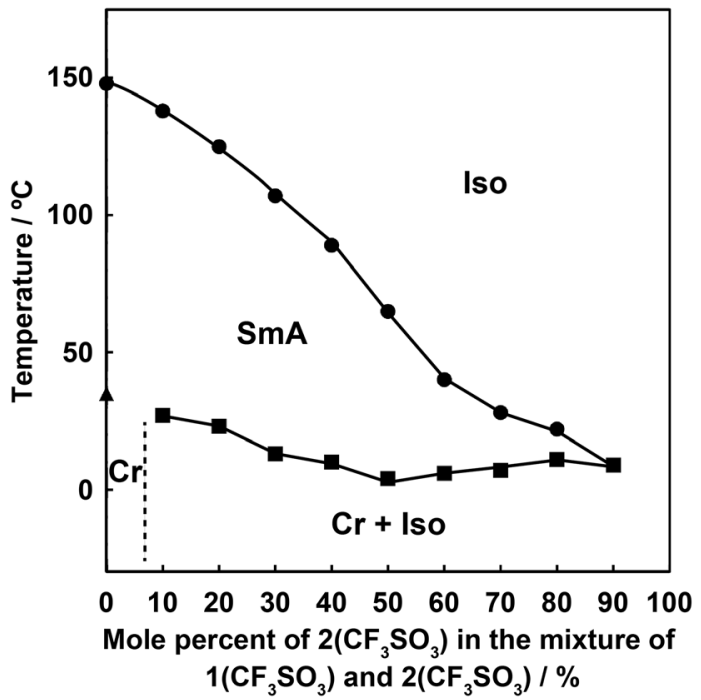

Fig. 2 Phase transition behavior of the mixtures of $\mathbf{1}\left(\mathrm{CF}_{3} \mathrm{SO}_{3}\right)$ and $\mathbf{2}\left(\mathrm{CF}_{3} \mathrm{SO}_{3}\right)$ on cooling. Iso: isotropic; SmA: smectic A; Cr: crystalline; $\mathrm{Cr}+$ Iso: biphasic mixture of crystalline and isotropic phases. The Iso-SmA transition temperatures for the mixtures containing more than $50 \mathrm{~mol} \%$ of $\mathbf{2}\left(\mathrm{CF}_{3} \mathrm{SO}_{3}\right)$ were determined by polarizing optical microscopic observations at a cooling rate of $1 \mathrm{~K} \mathrm{~min}^{-1}$.

that more stable LC structures are formed for $\mathbf{1}(\mathbf{X})$ with smaller counter anions. The charge density of a smaller anion is higher, leading to stronger electrostatic interactions between the anions and cations.

\section{Liquid-crystalline properties of the ionic liquid crystal and ionic liquid mixtures}

The mixtures of ionic liquid crystal $\mathbf{1}\left(\mathrm{CF}_{3} \mathbf{S O}_{3}\right)$ and ionic liquid $2\left(\mathbf{C F}_{3} \mathbf{S O}_{3}\right)$ were prepared. Fig. 2 shows the phase transition behavior of the mixtures on cooling. The mixtures show smectic A phases and form homeotropically aligned monodomains on glass substrates during cooling from isotropic states. A polarizing optical microscopic image of the mixture of $\mathbf{1}\left(\mathbf{C F}_{3} \mathbf{S O}_{3}\right)$ and $2\left(\mathbf{C F}_{3} \mathbf{S O}_{3}\right)$ in a $7: 3$ molar ratio is shown in Fig. 3a. A dark image and a cross-shaped pattern are observed under orthoscopic and conoscopic conditions, respectively. These observations confirm the vertical alignment of the LC molecules. This behavior is attributed to the interactions between the terminal imidazolium moieties of $\mathbf{1}\left(\mathbf{C F}_{3} \mathbf{S O}_{3}\right)$ and the hydrophilic surfaces of the unmodified glass substrates. ${ }^{13 b-d, 16}$ A macroscopic phase separation of the two components induced by the crystallization of $\mathbf{1}\left(\mathrm{CF}_{3} \mathrm{SO}_{3}\right)$ is observed at temperatures below those of the smectic A phases (ESI, $\dagger$ Fig. S9). In the LC states, compounds $\mathbf{1}\left(\mathbf{C F}_{3} \mathbf{S O}_{3}\right)$ and $2\left(\mathbf{C F}_{3} \mathbf{S O}_{3}\right)$ are compatible over a wide range of compositions. The mixtures containing up to $80 \mathrm{~mol} \%$ of $2\left(\mathbf{C F}_{3} \mathbf{S O}_{3}\right)$ form smectic LC structures. The high compatibility and high ability to form LC nanostructures of this system can be attributed to the similar chemical structures of the ionic moieties in $\mathbf{1}\left(\mathbf{C F}_{3} \mathbf{S O}_{3}\right)$ and $2\left(\mathbf{C F}_{3} \mathbf{S O}_{3}\right)$. In our previous studies, ${ }^{15,16}$ based on the mixtures of hydroxyl-functionalized amphiphilic molecules and ionic liquids, the components were not compatible when the molar percentage of the ionic liquid was higher than $70 \%$ and ionic liquids 
(a)

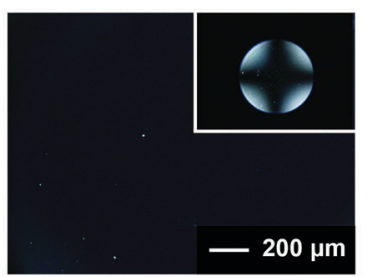

(b)

(c) the mixture. molar percentage of $2\left(\mathrm{CF}_{3} \mathbf{S O}_{3}\right)$.

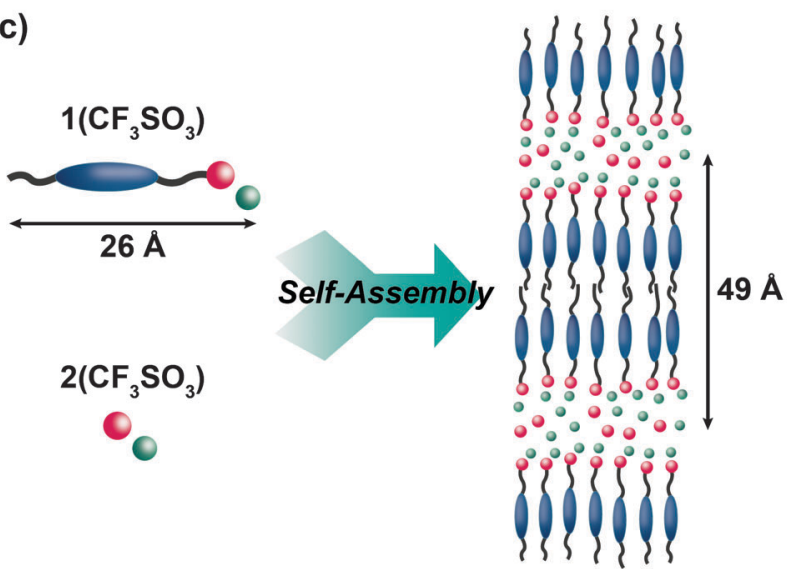

Fig. 3 (a) Polarizing optical microscopy image of the mixture of $1\left(\mathrm{CF}_{3} \mathrm{SO}_{3}\right)$ and $2\left(\mathrm{CF}_{3} \mathrm{SO}_{3}\right)$ in a $7: 3$ molar ratio at $100{ }^{\circ} \mathrm{C}$ on cooling. The inset shows the conoscopic image. (b) X-ray diffraction pattern of the mixture at $58{ }^{\circ} \mathrm{C}$ on cooling. (c) Schematic illustration of the self-assembled structure in

with anions larger than $\mathrm{BF}_{4}{ }^{-}$were not examined. The isotropization temperature of the mixture decreases with an increasing

The incorporation of an ionic liquid gives a more fluid LC nanostructure. The assembled structures of the mixtures of $\mathbf{1}\left(\mathbf{C F}_{3} \mathbf{S O}_{3}\right)$ and $\mathbf{2}\left(\mathbf{C F}_{3} \mathbf{S O}_{3}\right)$ were examined using X-ray diffraction. The pattern of the mixture of $\mathbf{1}\left(\mathbf{C F}_{3} \mathbf{S O}_{3}\right)$ and $\mathbf{2}\left(\mathbf{C F}_{3} \mathbf{S O}_{3}\right)$ in a $7: 3$ molar ratio at $58^{\circ} \mathrm{C}$ has two peaks at 50.2 and $24.3 \AA$, which are assigned to the (001) and (002) diffractions, respectively, of a layered structure with a spacing of $49 \AA$ (Fig. 3b). The layer spacing is twice the molecular length of $\mathbf{1}\left(\mathrm{CF}_{3} \mathbf{S O}_{3}\right)$, which is estimated to be $26 \AA$ by molecular mechanics calculations. This observation indicates the formation of a bilayered structure (Fig. 3c). The layer spacings of the structures are shown in Fig. 4; they increase with an increasing molar percentage of

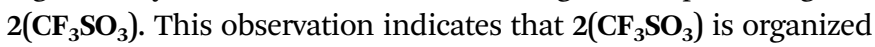
into ion-conductive layers formed by the imidazolium moiety in $\mathbf{1}\left(\mathrm{CF}_{3} \mathbf{S O}_{3}\right)$.

Ion-conductive properties of the ionic liquid crystals and ionic liquids mixtures

The ionic conductivity of $\mathbf{1}\left(\mathbf{C F}_{3} \mathbf{S O}_{3}\right)$ (ESI, $\dagger$ Fig. S10) and the mixtures of $\mathbf{1}\left(\mathbf{C F}_{3} \mathbf{S O}_{3}\right)$ and $2\left(\mathbf{C F}_{3} \mathbf{S O}_{3}\right)$ were determined using comb-shaped gold electrodes deposited on a glass substrate.

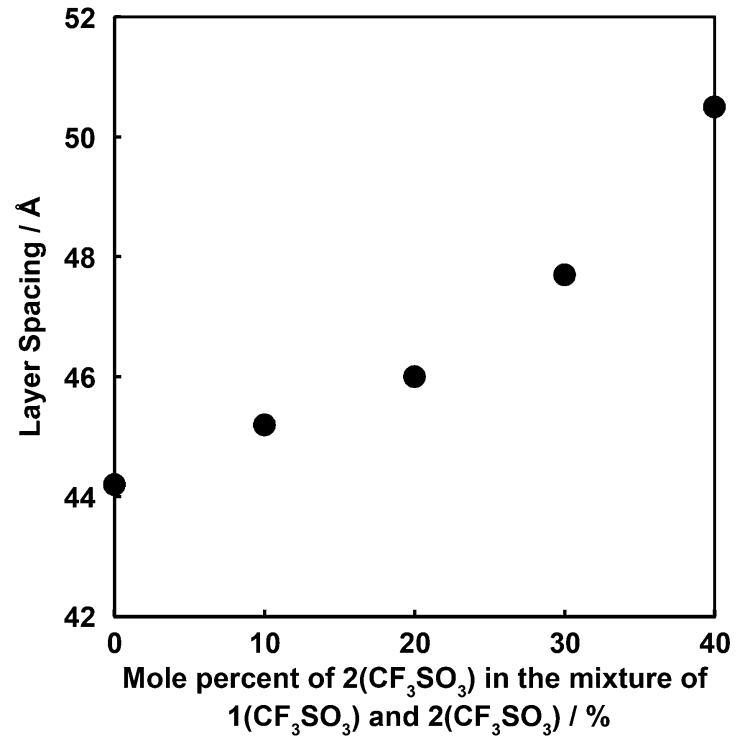

Fig. 4 Layer spacings of smectic LC structures formed by the mixtures of $\mathbf{1}\left(\mathrm{CF}_{3} \mathrm{SO}_{3}\right)$ and $\mathbf{2}\left(\mathrm{CF}_{3} \mathrm{SO}_{3}\right)$ at temperatures $30{ }^{\circ} \mathrm{C}$ below the isotropization temperature.

Fig. 5 shows the conductivities obtained on cooling from the isotropic states. In this process, a homeotropically aligned monodomain is spontaneously formed and this enables the measurement of the conductivities parallel to the ion-conductive pathways.

An increase in the molar percentage of $2\left(\mathrm{CF}_{3} \mathrm{SO}_{3}\right)$ increases the conductivity (Fig. 5). The ionic conductivities at $41{ }^{\circ} \mathrm{C}$ for $\mathbf{1}\left(\mathbf{C F}_{3} \mathbf{S O}_{3}\right)$ and the mixture of $\mathbf{1}\left(\mathrm{CF}_{3} \mathbf{S O}_{3}\right)$ and $2\left(\mathrm{CF}_{3} \mathbf{S O}_{3}\right)$ in a $6: 4$ molar ratio are $2.6 \times 10^{-5} \mathrm{~S} \mathrm{~cm}^{-1}$ and $2.9 \times 10^{-4} \mathrm{~S} \mathrm{~cm}^{-1}$, respectively. The conductivity is enhanced 10 -fold by the incorporation of $2\left(\mathbf{C F}_{3} \mathbf{S O}_{3}\right)$. To obtain more information on the ion-transport behavior of these materials in the smectic A phase, the activation energy for

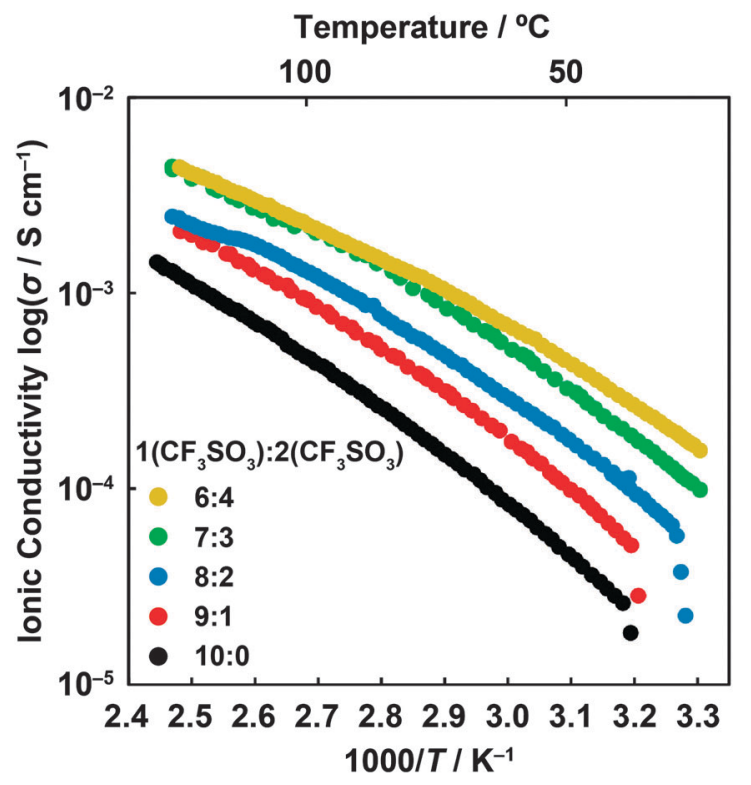

Fig. 5 Ionic conductivities of the mixtures of $1\left(\mathrm{CF}_{3} \mathrm{SO}_{3}\right)$ and $2\left(\mathrm{CF}_{3} \mathrm{SO}_{3}\right)$. 
ion conduction was calculated from the slopes of the Arrhenius plots shown in Fig. 5 using the Arrhenius conductivity equation $(\mathrm{ESI}, \dagger$ eqn (S1)). The activation energy is defined as the energy barrier that needs to be overcome for ions to migrate in the presence of intermolecular interactions. As the molar percentage of $2\left(\mathbf{C F}_{3} \mathbf{S O}_{3}\right)$ in the mixture increases, the activation energy gradually decreases from $50 \mathrm{~kJ} \mathrm{~mol}^{-1}$ for $\mathbf{1}\left(\mathbf{C F}_{3} \mathbf{S O}_{3}\right)$ to $36 \mathrm{~kJ} \mathrm{~mol}^{-1}$ for the mixture of $\mathbf{1}\left(\mathbf{C F}_{3} \mathbf{S O}_{3}\right)$ and $\mathbf{2}\left(\mathbf{C F}_{3} \mathbf{S O}_{3}\right)$ in a $6: 4$ molar ratio. These results suggest that more fluid ion-conductive pathways in which ions migrate with high mobility are formed in the mixtures containing an ionic liquid. In our previous report ${ }^{16 b}$ on non-covalent systems based on diol LC molecules with the same mesogenic moiety as $\mathbf{1}(\mathbf{X})$, the mixture containing $20 \mathrm{~mol} \%$ of an imidazolium ionic liquid showed a conductivity of $4.8 \times$ $10^{-4} \mathrm{~S} \mathrm{~cm}^{-1}$ at $122{ }^{\circ} \mathrm{C}$. In the present study, a conductivity of $2.0 \times 10^{-3} \mathrm{~S} \mathrm{~cm}^{-1}$ at the same temperature was achieved for a mixture of $\mathbf{1}(\mathbf{X})$ with the same molar percentage of an ionic liquid. ${ }^{16 b}$ The present system offers ionic conductivity one order of magnitude higher than that of the previous diol system. ${ }^{16 b}$ The activation energies for ion conduction in these systems are also almost the same.

\section{Liquid-crystalline properties of the mixtures containing lithium salts}

The mixtures consisting of $\mathbf{1}\left(\mathrm{CF}_{3} \mathbf{S O}_{3}\right), \mathbf{2}\left(\mathrm{CF}_{3} \mathbf{S O}_{3}\right)$, and $\mathrm{LiCF}_{3} \mathbf{S O}_{3}$ were prepared to evaluate the properties of these materials as lithium-ion conductors. The presence of $\mathbf{2}\left(\mathbf{C F}_{3} \mathbf{S O}_{3}\right)$ keeps the viscosity of the material low, resulting in enhanced lithium-ion transport. To examine the effect of the lithium salt concentration, a fixed molar ratio of $7: 3$ for $\mathbf{1}\left(\mathbf{C F}_{3} \mathbf{S O}_{3}\right)$ and $\mathbf{2}\left(\mathbf{C F}_{3} \mathbf{S O}_{3}\right)$ was used. Table 2 summarizes the phase transition behavior of the mixtures of $\mathbf{1}\left(\mathrm{CF}_{3} \mathbf{S O}_{3}\right), \mathbf{2}\left(\mathrm{CF}_{3} \mathbf{S O}_{3}\right)$, and $\mathbf{L i C F}_{3} \mathbf{S O}_{3}$. These mixtures also show smectic A phases with bilayered structures (ESI, $\dagger$ Fig. S8). The homeotropic alignment of the LC molecules on glass substrates on cooling from isotropic states was confirmed by the polarizing optical microscopic observations (ESI, $\dagger$ Fig. S8). The isotropization temperature is not significantly changed by the addition of $\mathbf{L i C F}_{3} \mathbf{S O}_{3}$. However, the crystallization temperature of $\mathbf{1}\left(\mathbf{C F}_{3} \mathbf{S O}_{3}\right)$ in the mixture decreases slightly with an increasing concentration of $\mathbf{L i C F}_{3} \mathbf{S O}_{3}$. For the mixture with a molar ratio of $7: 3: 1.5$, no crystallization of $\mathbf{1}\left(\mathrm{CF}_{3} \mathrm{SO}_{3}\right)$ occurs on cooling to $-30{ }^{\circ} \mathrm{C}$.

Table 2 The thermal properties of the mixtures of $\mathbf{1}\left(\mathrm{CF}_{3} \mathrm{SO}_{3}\right), \mathbf{2}\left(\mathrm{CF}_{3} \mathrm{SO}_{3}\right)$, and $\mathrm{LiCF}_{3} \mathrm{SO}_{3}$

\begin{tabular}{llllrl}
$\begin{array}{l}\text { Molar ratio of } \mathbf{1}\left(\mathbf{C F}_{3} \mathbf{S O}_{\mathbf{3}}\right), \\
\mathbf{2}\left(\mathbf{C F}_{3} \mathbf{S O}_{3}\right) \text {, and } \mathbf{L i C F} \mathbf{S O}_{3}\end{array}$ & \multicolumn{5}{l}{ Phase transition behavior ${ }^{a, b}$} \\
\hline $7: 3: 0$ & Iso & 107 & $\mathrm{SmA}$ & 13 & $\mathrm{Cr}+$ Iso \\
$7: 3: 0.375$ & Iso & 109 & $\mathrm{SmA}$ & 10 & $\mathrm{Cr}+$ Iso \\
$7: 3: 0.75$ & Iso & 109 & $\mathrm{SmA}$ & 6 & $\mathrm{Cr}+$ Iso \\
$7: 3: 1.5$ & Iso & 109 & $\mathrm{SmA}$ & &
\end{tabular}

${ }^{a}$ Transition temperatures $\left({ }^{\circ} \mathrm{C}\right)$ are determined using differential scanning calorimetry (DSC) on the first cooling at a scan rate of $10 \mathrm{~K} \mathrm{~min}^{-1}$. ${ }^{b}$ Iso: isotropic; SmA: smectic A; Cr: crystalline; $\mathrm{Cr}+$ Iso: biphasic mixture of crystalline and isotropic phases.

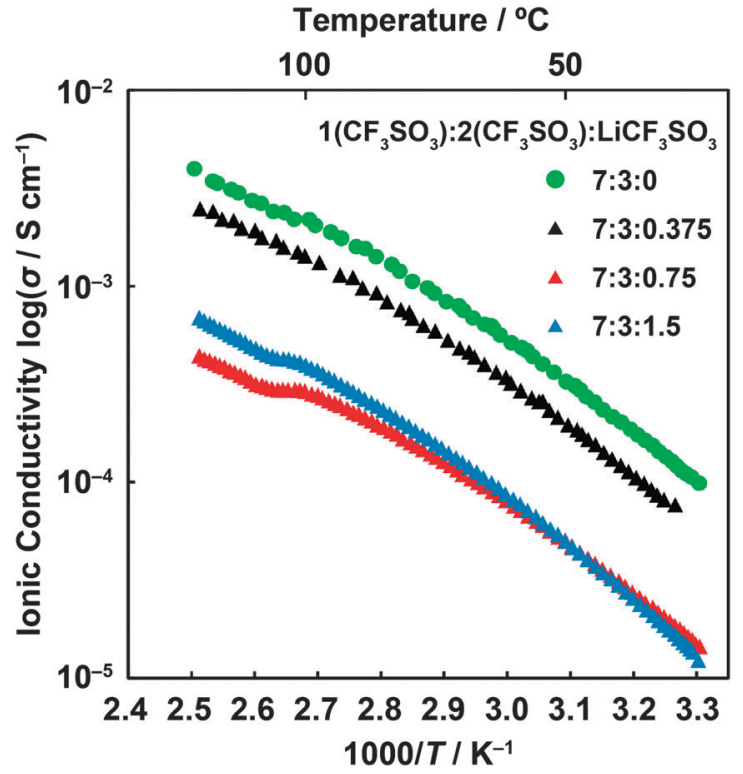

Fig. 6 Ionic conductivities of the mixtures of $\mathbf{1}\left(\mathrm{CF}_{3} \mathrm{SO}_{3}\right), \mathbf{2}\left(\mathrm{CF}_{3} \mathrm{SO}_{3}\right)$, and $\mathrm{LiCF}_{3} \mathrm{SO}_{3}$

Ion-conductive properties of the mixtures containing lithium salts

The ion-conductive properties of the mixtures containing $\mathbf{L i C F}_{3} \mathbf{S O}_{3}$ were examined. Fig. 6 shows the Arrhenius plots of the ionic conductivity during cooling from the isotropic state. The addition of $\mathbf{L i C F}_{3} \mathbf{S O}_{3}$ results in a decrease in the conductivity; this is attributed to the lower mobility found in the ion-conductive pathways derived from the formation of aggregated species ${ }^{21}$ through the coordination of the anions to the lithium cations (ESI, $\dagger$ Fig. S11). It has been reported for isotropic ionic liquids ${ }^{22}$ that binary mixtures of ionic liquids and lithium salts show lower conductivities and higher viscosities than the ionic liquids themselves; this is also explained by a decrease in the ionic mobility as a result of ion association.

\section{Liquid-crystalline properties of the ionic liquid crystals and ionic liquids mixtures with different counter anions}

The effects of the co-existence of two types of counter anions on the LC behavior were studied by mixing $\mathbf{1}\left(\mathrm{CF}_{3} \mathbf{S O}_{3}\right)$ and $\mathbf{2}(\mathrm{X})$ $\left[\mathrm{X}=\mathrm{BF}_{4}\right.$ or $\left.\left(\mathrm{CF}_{3} \mathrm{SO}_{2}\right)_{2} \mathrm{~N}\right]$. The phase diagrams of the mixtures on cooling are shown in Fig. 7. The mixtures show smectic A phases. The two components are compatible in the LC states over the entire composition range, which indicates that $\mathbf{1}\left(\mathbf{C F}_{3} \mathbf{S O}_{3}\right)$ has high compatibility with $\mathbf{2}(\mathrm{X})$, regardless of the counter anion. When the molar percentage of $2(\mathrm{X})$ is $30 \%$ or higher, $\mathbf{1}\left(\mathbf{C F}_{3} \mathbf{S O}_{3}\right)$ does not crystallize on cooling to $-30{ }^{\circ} \mathbf{C}$, although crystallization is observed for the mixtures of $\mathbf{1}\left(\mathrm{CF}_{3} \mathbf{S O}_{3}\right)$ and $\mathbf{2}\left(\mathrm{CF}_{3} \mathbf{S O}_{3}\right)$. The isotropization temperature decreases with an increasing radius of the counter anion of $2(\mathrm{X})$ (ESI, $\dagger$ Fig. S12). ${ }^{20}$ The addition of $2(\mathrm{X})$ with large counter anions destabilizes the LC phase. 
(a)

(b)

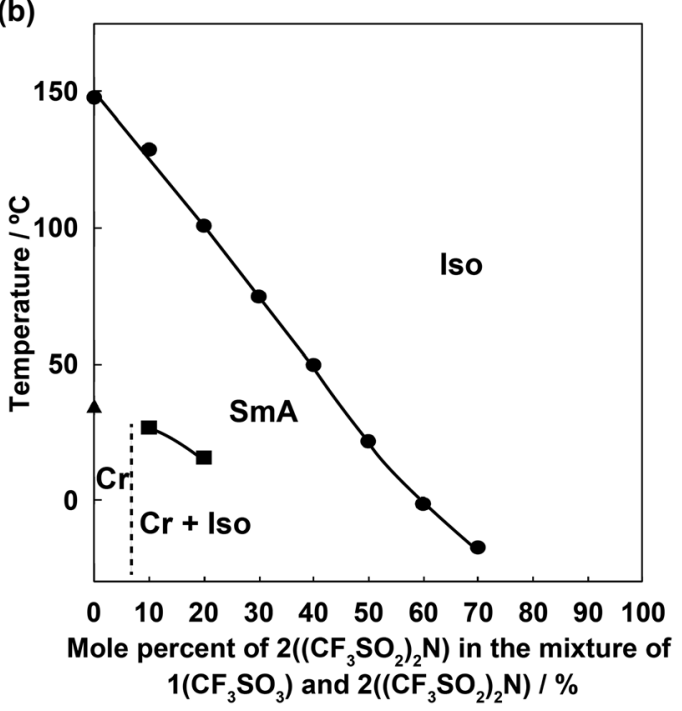

Fig. 7 Phase transition behavior of the mixtures of (a) $1\left(\mathrm{CF}_{3} \mathrm{SO}_{3}\right)$ and 2( $\left(\mathrm{BF}_{4}\right)$, and (b) $\mathbf{1}\left(\mathrm{CF}_{3} \mathrm{SO}_{3}\right)$ and $\mathbf{2}\left(\left(\mathrm{CF}_{3} \mathrm{SO}_{2}\right)_{2} \mathrm{~N}\right)$ on cooling. Iso: isotropic; SmA: smectic $\mathrm{A}$; $\mathrm{Cr}$ : crystalline; $\mathrm{Cr}+$ Iso: biphasic mixture of crystalline and isotropic phases. The Iso-SmA transition temperature for the mixture containing $90 \mathrm{~mol} \%$ of $\mathbf{2}\left(\mathbf{B F}_{4}\right)$ was determined by polarizing optical microscopic observation at a cooling rate of $1 \mathrm{~K} \mathrm{~min}^{-1}$.

\section{Conclusions}

Calamitic ionic liquid crystals containing an imidazolium cation form 2D ion-conductive pathways; moreover, the imidazolium ionic liquids with various counter anions are organized at high molar fractions. The structural similarities of the ionic moieties in the two components provide high compatibility in forming liquid-crystalline layered nanostructures. An enhancement in the ionic conductivity is achieved by their co-existence with ionic liquids. The liquid-crystalline mixtures of ionic liquid crystals, ionic liquids, and lithium salts were also prepared as lithium-ion conductors. Materials designed using the non-covalent self-assembly of ionic liquid crystals and ionic liquids have potential in the development of functional liquid-crystalline assemblies based on ionic liquids, which could be used as new functional electrolytes for energy devices. ${ }^{2 j, 18}$

\section{Experimental section}

\section{General procedures}

${ }^{1} \mathrm{H}$ and ${ }^{13} \mathrm{C}$ NMR spectra were obtained using a JEOL JNMLA400 at 400 and $100 \mathrm{MHz}$ in $\mathrm{CDCl}_{3}$, respectively. Chemical shifts of the ${ }^{1} \mathrm{H}$ and ${ }^{13} \mathrm{C}$ NMR signals are quoted with respect to $\mathrm{Me}_{4} \mathrm{Si}(\delta=0.00)$ and $\operatorname{CDCl}_{3}(\delta=77.0)$ as internal standards, respectively; the chemical shifts in parts per million $(\delta)$, multiplicities, coupling constants $(\mathrm{Hz})$, and relative intensities are reported. FTIR measurements were conducted using a JASCO FT/IR-660 Plus spectrometer. Matrix-assisted laser desorption ionization time-of-flight mass spectra were obtained using a PerSeptive Biosystems Voyager-DE STR spectrometer with dithranol as the matrix. Elemental analyses were performed using an Exeter Analytical CE440 elemental analyzer. The thermal properties of the materials were examined by differential scanning calorimetry using a Netzsch DSC204 Phoenix. The heating and cooling rates were $10 \mathrm{~K} \mathrm{~min}^{-1}$. Transition temperatures were taken at the onsets of the transition peaks. A polarizing optical microscope Olympus BX51 equipped with a Linkam LTS350 hot stage was used to study liquid crystallinity. X-ray diffraction patterns were obtained using a Rigaku RINT-2500 diffractometer with $\mathrm{CuK} \alpha$ radiation.

\section{Ionic conductivity measurements}

The temperature dependence of the ionic conductivities were investigated by the alternating current impedance method using a Solartron 1260 impedance/gain-phase analyzer (frequency range: $100 \mathrm{~Hz}-1 \mathrm{MHz}$, applied voltage: $0.6 \mathrm{~V}$ ) equipped with a temperature controller. The heating and cooling rates were fixed at $2 \mathrm{~K} \mathrm{~min}{ }^{-1}$. The ionic conductivities were calculated as the product of $1 / R_{\mathrm{b}}\left(\Omega^{-1}\right)$ times the cell constants $\left(\mathrm{cm}^{-1}\right)$ for the electrode cells, which were calibrated with $\mathrm{KCl}$ aqueous solution $\left(1.00 \mathrm{mmol} \mathrm{L}^{-1}\right)$ as a standard conductive solution. The impedance data were modeled as a connection of two RC circuits in series.

\section{Acknowledgements}

This study was partially supported by the Funding Program for World-Leading Innovative R\&D on Science and Technology (FIRST) from the Cabinet Office, Government of Japan. J. S. is grateful for the financial support from the JSPS Research Fellowships for Young Scientists.

\section{Notes and references}

1 (a) in Handbook of Liquid Crystals, ed. J. W. Goodby, P. J. Collings, T. Kato, C. Tschierske, H. Gleeson and P. Raynes, Wiley-VCH, Weinheim, 2nd edn, 2014; (b) K. Binnemans, Chem. Rev., 2005, 105, 4148-4204; (c) T. Kato, N. Mizoshita and K. Kishimoto, Angew. Chem., Int. Ed., 2006, 45, 38-68; 
(d) B. R. Wiesenauer and D. L. Gin, Polym. J., 2012, 44, 461-468; (e) A. P. H. J. Schenning, Y. C. Gonzalez-Lemus, I. K. Shishmanova and D. J. Broer, Liq. Cryst., 2011, 38, 1627-1639; $(f)$ T. Kato, T. Yasuda, Y. Kamikawa and M. Yoshio, Chem. Commun., 2009, 729-739; (g) C. Tschierske, Chem. Soc. Rev., 2007, 36, 1930-1970; (h) J. W. Goodby, E. J. Davis, R. J. Mandle and S. J. Cowling, Isr. J. Chem., 2012, 52, 863-880; (i) B. Donnio, S. Buathong, I. Bury and D. Guillon, Chem. Soc. Rev., 2007, 36, 1495-1513; (j) B. M. Rosen, C. J. Wilson, D. A. Wilson, M. Peterca, M. R. Imam and V. Percec, Chem. Rev., 2009, 109, 6275-6540; (k) H. K. Bisoyi and S. Kumar, Chem. Soc. Rev., 2011, 40, 306-319; (l) H. Kikuchi, Struct. Bonding, 2008, 128, 99-117.

2 (a) T. Kato, Angew. Chem., Int. Ed., 2010, 49, 7847-7848; (b) M. Funahashi, H. Shimura, M. Yoshio and T. Kato, Struct. Bonding, 2008, 128, 151-179; (c) B.-K. Cho, Polym. J., 2012, 44, 475-489; (d) B.-K. Cho, RSC Adv., 2014, 4, 395-405; (e) B.-K. Cho, A. Jain, S. M. Gruner and U. Wiesner, Science, 2004, 305, 1598-1601; $(f)$ G. S. McHattie, C. T. Imrie and M. D. Ingram, Electrochim. Acta, 1998, 43, 1151-1154; (g) O. Ikkala and G. ten Brinke, Chem. Commun., 2004, 2131-2137; (h) Y. Zheng, J. Lui, G. Ungar and P. V. Wright, Chem. Rec., 2004, 4, 176-191; (i) R. L. Kerr, S. A. Miller, R. K. Shoemaker, B. J. Elliott and D. L. Gin, J. Am. Chem. Soc., 2009, 131, 15972-15973; (j) J. Sakuda, E. Hosono, M. Yoshio, T. Ichikawa, T. Matsumoto, H. Ohno, H. Zhou and T. Kato, Adv. Funct. Mater., 2015, 25, 1206-1212.

3 (a) S. Sergeyev, W. Pisula and Y. H. Geerts, Chem. Soc. Rev., 2007, 36, 1902-1929; (b) Y. Shimizu, K. Oikawa, K. Nakayama and D. Guillon, J. Mater. Chem., 2007, 17, 4223-4229; (c) J. Wu, W. Pisula and K. Müllen, Chem. Rev., 2007, 107, 718-747; (d) M. Funahashi, Polym. J., 2009, 41, 459-469.

4 (a) D. L. Gin and R. D. Noble, Science, 2011, 332, 674-676; (b) M. Zhou, P. R. Nemade, X. Lu, X. Zeng, E. S. Hatakeyama, R. D. Noble and D. L. Gin, J. Am. Chem. Soc., 2007, 129, 9574-9575; (c) M. Henmi, K. Nakatsuji, T. Ichikawa, H. Tomioka, T. Sakamoto, M. Yoshio and T. Kato, Adv. Mater., 2012, 24, 2238-2241.

5 (a) D. L. Gin, W. Gu, B. A. Pindzola and W.-J. Zhou, Acc. Chem. Res., 2001, 34, 973-980; (b) D. L. Gin and W. Gu, Adv. Mater., 2001, 13, 1407-1410; (c) Y. Ishida, Y. Kai, S. Kato, A. Misawa, S. Amano, Y. Matsuoka and K. Saigo, Angew. Chem., Int. Ed., 2008, 47, 8241-8245.

6 T. Kato, Science, 2002, 295, 2414-2418.

7 (a) C. Tschierske, Isr. J. Chem., 2012, 52, 935-959; (b) C. Tschierske, Angew. Chem., Int. Ed., 2013, 52, 8828-8878. 8 (a) in Electrochemical Aspects of Ionic Liquids, ed. H. Ohno, John Wiley - Sons, Hoboken, 2nd edn, 2011; (b) H. Ohno, Bull. Chem. Soc. Jpn., 2006, 79, 1665-1680; (c) M. Armand, F. Endres, D. R. MacFarlane, H. Ohno and B. Scrosati, Nat. Mater., 2009, 8, 621-629; (d) D. R. MacFarlane, N. Tachikawa, M. Forsyth, J. M. Pringle, P. C. Howlett, G. D. Elliott, J. H. Davis Jr., M. Watanabe, P. Simon and C. A. Angell, Energy Environ. Sci., 2014, 7, 232-250; (e) T. Welton, Chem. Rev., 1999, 99, 2071-2083; (f) P. Wasserscheid and W. Keim, Angew. Chem., Int. Ed., 2000, 39, 3772-3789; ( $g$ ) A. Lewandowski and A. ŚwiderskaMocek, J. Power Sources, 2009, 194, 601-609.

9 M. J. Earle, J. M. S. S. Esperança, M. A. Gilea, J. N. Canongia Lopes, L. P. N. Rebelo, J. W. Magee, K. R. Seddon and J. A. Widegren, Nature, 2006, 439, 831-834.

10 M. Smiglak, W. M. Reichert, J. D. Holbrey, J. S. Wilkes, L. Sun, J. S. Thrasher, K. Kirichenko, S. Singh, A. R. Katritzky and R. D. Rogers, Chem. Commun., 2006, 2554-2556.

11 (a) M. Galiński, A. Lewandowski and I. Stępniak, Electrochim. Acta, 2006, 51, 5567-5580; (b) P. Bonhôte, A.-P. Dias, N. Papageorgiou, K. Kalyanasundaram and M. Grätzel, Inorg. Chem., 1996, 35, 1168-1178.

12 (a) M. Yoshio, T. Mukai, H. Ohno and T. Kato, J. Am. Chem. Soc., 2004, 126, 994-995; (b) M. Yoshio, T. Ichikawa, H. Shimura, T. Kagata, A. Hamasaki, T. Mukai, H. Ohno and T. Kato, Bull. Chem. Soc. Jpn., 2007, 80, 1836-1841; (c) S. Yazaki, Y. Kamikawa, M. Yoshio, A. Hamasaki, T. Mukai, H. Ohno and T. Kato, Chem. Lett., 2008, 37, 538-539; (d) M. Yoshio, T. Kagata, K. Hoshino, T. Mukai, H. Ohno and T. Kato, J. Am. Chem. Soc., 2006, 128, 5570-5577; (e) J. Motoyanagi, T. Fukushima and T. Aida, Chem. Commun., 2005, 101-103.

13 (a) C. J. Bowlas, D. W. Bruce and K. R. Seddon, Chem. Commun., 1996, 1625-1626; (b) M. Yoshio, T. Mukai, K. Kanie, M. Yoshizawa, H. Ohno and T. Kato, Chem. Lett., 2002, 320-321; (c) T. Mukai, M. Yoshio, T. Kato, M. Yoshizawa and H. Ohno, Chem. Commun., 2005, 1333-1335; (d) K. Hoshino, M. Yoshio, T. Mukai, K. Kishimoto, H. Ohno and T. Kato, J. Polym. Sci., Part A: Polym. Chem., 2003, 41, 3486-3492; (e) S. Ujiie and K. Iimura, Chem. Lett., 1990, 995-998; $(f)$ D. Navarro-Rodriguez, Y. Frere, P. Gramain, D. Guillon and A. Skoulios, Liq. Cryst., 1991, 9, 321-335; (g) D. J. Abdallah, A. Robertson, H.-F. Hsu and R. G. Weiss, J. Am. Chem. Soc., 2000, 122, 3053-3062.

14 (a) T. Ichikawa, M. Yoshio, A. Hamasaki, T. Mukai, H. Ohno and T. Kato, J. Am. Chem. Soc., 2007, 129, 10662-10663; (b) T. Ichikawa, M. Yoshio, A. Hamasaki, S. Taguchi, F. Liu, X. Zeng, G. Ungar, H. Ohno and T. Kato, J. Am. Chem. Soc., 2012, 134, 2634-2643; (c) T. Ichikawa, M. Yoshio, A. Hamasaki, J. Kagimoto, H. Ohno and T. Kato, J. Am. Chem. Soc., 2011, 133, 2163-2169; (d) B. Soberats, M. Yoshio, T. Ichikawa, S. Taguchi, H. Ohno and T. Kato, J. Am. Chem. Soc., 2013, 135, 15286-15289.

15 H. Shimura, M. Yoshio, K. Hoshino, T. Mukai, H. Ohno and T. Kato, J. Am. Chem. Soc., 2008, 130, 1759-1765.

16 (a) M. Yoshio, T. Mukai, K. Kanie, M. Yoshizawa, H. Ohno and T. Kato, Adv. Mater., 2002, 14, 351-354; (b) M. Yoshio, T. Kato, T. Mukai, M. Yoshizawa and H. Ohno, Mol. Cryst. Liq. Cryst., 2004, 413, 2235-2244.

17 (a) T. Ichikawa, M. Yoshio, S. Taguchi, J. Kagimoto, H. Ohno and T. Kato, Chem. Sci., 2012, 3, 2001-2008; (b) T. Ichikawa, K. Fujimura, M. Yoshio, T. Kato and H. Ohno, Chem. Commun., 2013, 49, 11746-11748.

18 (a) D. Högberg, B. Soberats, S. Uchida, M. Yoshio, L. Kloo, H. Segawa and T. Kato, Chem. Mater., 2014, 26, 6496-6502; 
(b) N. Yamanaka, R. Kawano, W. Kubo, N. Masaki, T. Kitamura, Y. Wada, M. Watanabe and S. Yanagida, J. Phys. Chem. B, 2007, 111, 4763-4769; (c) R. D. Costa, F. Werner, X. Wang, P. Grönninger, S. Feihl, F. T. U. Kohler, P. Wasserscheid, S. Hibler, R. Beranek, K. Meyer and D. M. Guldi, Adv. Energy Mater., 2013, 3, 657-665.

19 A. Noda, K. Hayamizu and M. Watanabe, J. Phys. Chem. B, 2001, 105, 4603-4610.

20 M. Ue, A. Murakami and S. Nakamura, J. Electrochem. Soc., 2002, 149, A1385-A1388.

21 (a) C. M. Burba, N. M. Rocher, R. Frech and D. R. Powell, J. Phys. Chem. B, 2008, 112, 2991-2995; (b) Q. Zhou,
K. Fitzgerald, P. D. Boyle and W. A. Henderson, Chem. Mater., 2010, 22, 1203-1208; (c) K. Matsumoto, R. Hagiwara and O. Tamada, Solid State Sci., 2006, 8, 1103-1107.

22 (a) B. Garcia, S. Lavallée, G. Perron, C. Michot and M. Armand, Electrochim. Acta, 2004, 49, 4583-4588; (b) K. Hayamizu, Y. Aihara, H. Nakagawa, T. Nukuda and W. S. Price, J. Phys. Chem. B, 2004, 108, 19527-19532; (c) J.-W. Park, K. Yoshida, N. Tachikawa, K. Dokko and M. Watanabe, J. Power Sources, 2011, 196, 2264-2268; (d) B. Singh and S. S. Sekhon, J. Phys. Chem. B, 2005, 109, 16539-16543. 